\title{
ANALISA PERGESERAN FASA PADA PERANCANGAN DAN REALISASI BRANCH-LINE COUPLER UNTUK DETEKSI FASA PADA RADAR C-BAND
}

\author{
Arrizky Ayu Faradila Purnama ${ }^{1}$, Aloysius Adya Pramudita ${ }^{2}$, Edwar $^{3}$ \\ 1, 2, 3 Fakultas Teknik Elektro, Universitas Telkom \\ ${ }^{4}$ Lembaga Ilmu Pengetahuan Indonesia \\ 1 arrzkyafp123@gmail.com, ${ }^{2}$ pramuditaadya@gmail.com, \\ 3eduatgugel@gmail.com
}

\begin{abstract}
Abstrak
Sejumlah radar menggunakan I/Q demodulator pada sisi penerima untuk melakukan pengolahan sinyal pantul dari objek yang diterimanya. I/Q demodulator merupakan suatu komponen yang berfungsi untuk memproses sinyal RF ke sinyal I (In-phase) dan sinyal Q (Quadrature). Pada I/Q demodulator, sinyal masukkan akan dikalikan dengan dua sinyal dari LO (Local Oscillator) yang masing-masing berbeda fasa 90 yang kemudian digunakan sebagai mekanisme pendeteksi fasa. Branch-line coupler merupakan suatu rangkaian penggeser fasa yang dapat diimplementasikan dalam membangun I/Q demodulator. Akurasi pergeseran fasa yang dihasilkan branch-line coupler akan memberikan pengaruh terhadap hasil deteksi fasanya. Dalam perancangan dan realisasi branch-line coupler diperlukan suatu kajian untuk mengetahui ketepatan pergeseran fasa yang diperoleh. Pada penelitian ini dilakukan, suatu analisa kerja branch-line coupler hasil dari suatu perancangan dan realisasi yang telah dilakukan untuk suatu deteksi fasa pada radar $C$-band dengan basis I/Q demodulator. Hasil penelitian menunjukkan bahwa nilai pergeseran yang mendekati 90 menyebabkan nilai fasa sinyal keluaran sebanding dengan fasa sinyal datang.

Kata Kunci: I/Q Demodulator, Branch-Line Coupler, Penggeser Fasa
\end{abstract}

\begin{abstract}
Various of radars use $I / Q$ demodulator at their receiver to perform a signal processing reflection from the receiving object. I/Q demodulator is a component that used to process $R F$ signal to $I$ (In-phase) signal and $Q$ (Quadrature) signal. The input signal will be multiplied with two signals from the LO (Local Oscillator) that have 90 phase difference, and, after that the signal will be used as phase detector mechanism at I/Q demodulator. Branch-line coupler is a phase shifter circuit that can be implemented at I/Q demodulator development. The phase shift accuracy produced by the branch-line coupler will have an effect on the phase detection results. In the design and realization of branch-line couplers, a research is requied to determine the accuracy of phase shifts obtained. This study analyzer of the performance of branch-line coupler produced from a design and the realization that has been done for a phase detector on $C$-band radars using $I / Q$ demodulator base. The results of the study showed that the shift value reaching 90, that furthemore will cause the output signal phase value to be proportional to the incoming signal phase.
\end{abstract}

Key Words: I/Q Demodulator, Branch-Line Coupler, Phase Shifter

\section{Pendahuluan}

Radar dapat dimanfaatkan untuk mengukur jarak, mendeteksi mengenai perubahan cuaca, dan membuat pemetaan benda-benda. Sistem radar merupakan suatu metode pengindraan jarak jauh menggunakan gelombang elektromagnetik yang dipancarkan oleh antena transmitter kemudian dipantulkan oleh objek dan akan diterima oleh antena receiver, sehingga sinyal yang diterima pada antena receiver akan dianalisa dan diproses [1]. Dalam pemrosesan sinyal, sejumlah radar menggunakan I/Q demodulator pada bagian penerima untuk menerima untuk melakukan pengolahan sinyal yang diterima pada antenna receiver.

I/Q Demodulator merupakan suatu komponen yang berfungsi untuk memproses sinyal Radio Frekuensi (RF) ke sinyal analog I (In-phase) dan sinyal Q (Quadrature). Pada I/Q Demodulator, sinyal masukkan akan dikalikan dengan dua sinyal dari LO (Local Oscillator) yang masing-masing berbeda fasa 90. Hasil perkalian tersebut adalah sinyal keluaran yang disebut sinyal I (In-phase) 
dan sinyal Q (Quadrature) [2]. Dalam komponen I/Q Demodulator diperlukan rangkaian penggeser fasa yang digunakan untuk membagi sinyal LO menjadi dua buah sinyal yang berbeda fasa sebesar 90. Salah satu rangkaian dengan karakteristik penggeser fasa 90 adalah branch-line coupler.

Branch-line coupler merupakan multiport network dengan keseluruhan port-nya saling bersesuaian satu dengan yang lain dan memiliki karakteristik menggeser fasa keluarannya sebesar 90 [3]. Branch-line coupler biasanya digunakan pada sebagian besar perangkat yang mencangkup amplifier, mixer, dan banyak digunakan sebagai rangkaian penggeser fasa maupun pembagi daya [4]. Akurasi pergeseran fasa yang dihasilkan branch-line coupler akan memberikan pengaruh terhadap hasil deteksi fasanya. Dalam perancangan dan realisasi branch-line coupler diperlukan suatu kajian untuk mengetahui ketepatan pergeseran fasa yang diperoleh. Penelitian ini dilakukan untuk menganalisa kerja branch-line coupler hasil dari suatu perancangan dan realisasi yang telah dilakukan untuk suatu deteksi fasa pada radar $C$-band (5700-5900 MHz)

\section{Dasar Teori}

\subsection{Radar}

Radio Detecting and Ranging atau yang lebih dikenal dengan istilah radar merupakan sebuah sistem dengan menggunakan gelombang elektromagnetik yang digunakan untuk mendeteksi, mengukur jarak, dan membuat pemetaan benda-benda, serta mendeteksi mengenai perubahan cuaca. Prinsip kerja radar adalah dengan memanfaatkan konsep transmitter - receiver ketika gelombang elektromagnetik dipancarkan oleh antena transmitter, kemudian dipantulkan oleh target dan akan diterima oleh antena receiver. Sinyal yang diterima pada receiver selanjutnya akan dianalisa dan diproses, sehingga target dapat terdeteksi[1]. Pergeseran fasa yang terjadi pada sinyal pantul berkaitan dengan jarak target, sehingga kemampuan kinerja deteksi fasa akan mempengaruhi akurasi deteksi jarak target. Adapun prinsip kerja radar dijealskan seperti pada Gambar 1.

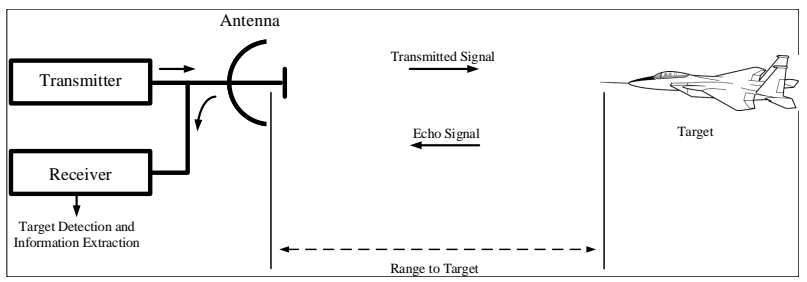

Gambar 1. Prinsip Kerja Radar

\section{$2.2 \quad$ I/Q Demodulator}

$I / Q$ demodulator merupakan komponen pemrosesan sinyal RF langsung ke sinyal analog I
(In-phase) dan sinyal Q (Quadrature) dan kemudian dikonversi menjadi data digital. I/Q demodulator diilustrasikan pada Gambar 2. Fungsi I/Q demodulator didasarkan pada sinyal input RF yang dipecah dan dikali dengan dua sinyal dari LO (Local Oscillator) yang salah satu fasanya digeser sebesar 90 . Pergeseran fasa ini akan membedakan sinyal I (In-phase) dan Q (Quadrature) [2][5].

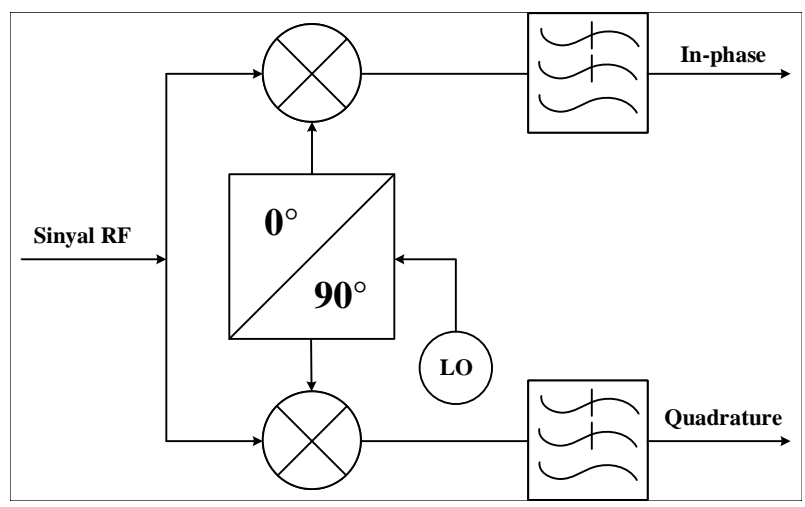

Gambar 2. I/Q Demodulator

Pengoperasian I/Q demodulator dapat dijelaskan dengan mewakili sinyal input RF sebagai kombinasi dari dua carrier quadrature termodulasi [6], megikuti persamaan (1) dan (2):

$$
\begin{gathered}
X_{R F}(t)=X_{i}(t)+X_{Q}(t) \\
X_{R F}=X_{i} \cos \left(2 \pi f_{0} t\right)+X_{Q} \cos \left(2 \pi f_{0} t\right)
\end{gathered}
$$

\subsection{Branch-Line Coupler}

Coupler merupakan komponen gelombang mikro pasif yang digunakan sebagai pembagi daya dan penggabung daya, yang diilustrasikan pada Gambar 3. Pada pembagi daya, sinyal masukkan akan dibagi menjadi dua atau lebih sinyal keluaran, sebaliknya pada penggabungan sinyal akan menerima dua atau lebih sinyal masukkan dan akan dikombinasikan sinyal-sinyal tersebut pada port keluaran [3].

Branch-line coupler merupakan multiport network dengan keseluruhan port-nya saling bersesuaian dengan karakteristik menggeser fasa keluarannya sebesar 90. Branch-line coupler digunakan dalam perangkat gelombang mikro pada mixer, power amplifier, modulator, dan array antenna [7]. Coupler ini terdiri dari dua jalur transmisi utama yang dihubungkan dengan dua jalur sekunder (jalur cabang). Port pertama (P1) sebagai input port, port kedua (P2) dan ketiga (P3) sebagai output port dan port keempat (P4) adalah isolation port . Adapun model branch-line coupler sebagai rangkaian penggeser fasa ditunjukkan pada Gambar 4

Prinsip kerja pada branch-line coupler dengan semua port dalam keadaan matched, daya yang masuk ke 


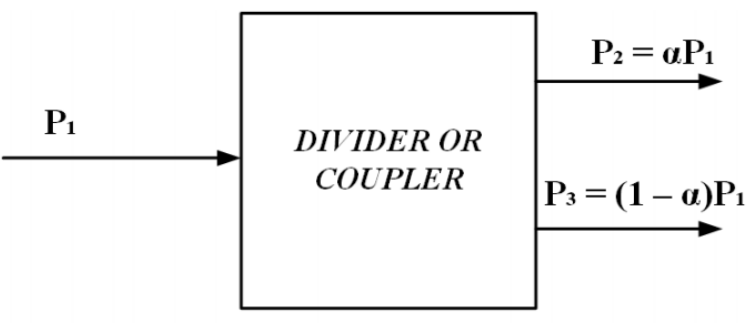

(a)

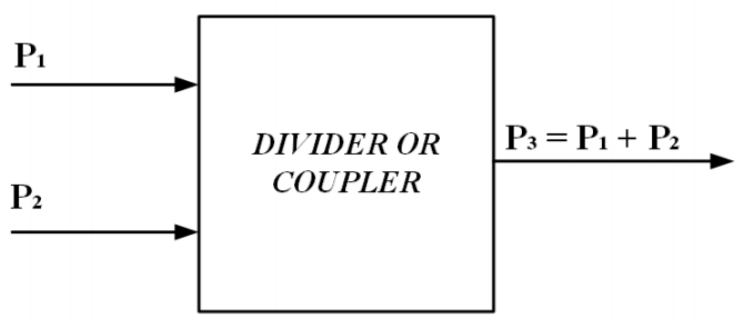

(b)

Gambar 3. (a) Pembagi Daya dan (b) Penggabung Daya

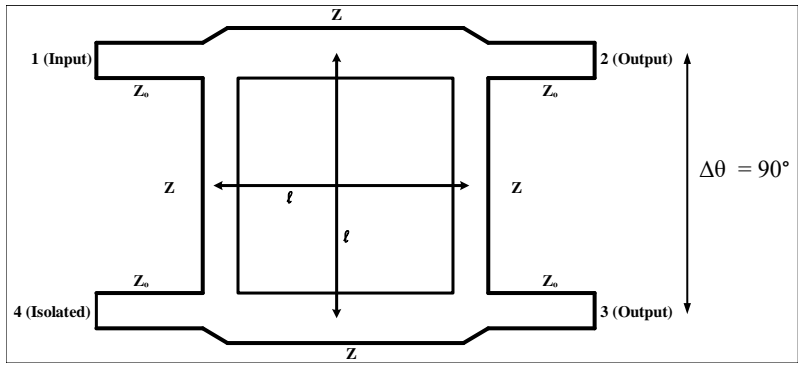

Gambar 4. Branch-Line Coupler

port-1 (P1) dibagi rata antara port-2 (P2) dengan port-3 (P3), pada kedua output port terjadi pergeseran fasa sebesar 90. Tidak ada daya diteruskan ke port-4 (P4) [3].

\section{Hasil Pergeseran Fasa}

Untuk menyatakan bahwa branch-line coupler memiliki kararakteristik sebagai rangkaian penggeser fasa, maka parameter yang dianalisis adalah selisih fasa antara port-2 (S12) dan port-3 (S13). Hasil dari pergeseran fasa didapatkan dalam du acara yaitu simulasi dengan menggunakan software 3D electromagnetic design dan pengukuran pada realisasi branch-line coupler dengan menggunakan Vector Network Analyzer T5280A $300 \mathrm{KHz} 8 \mathrm{GHz}$. Adapun skenario pengukuran untuk mendapatkan pergeseran fasa ditunjukkan pada Gambar 5.

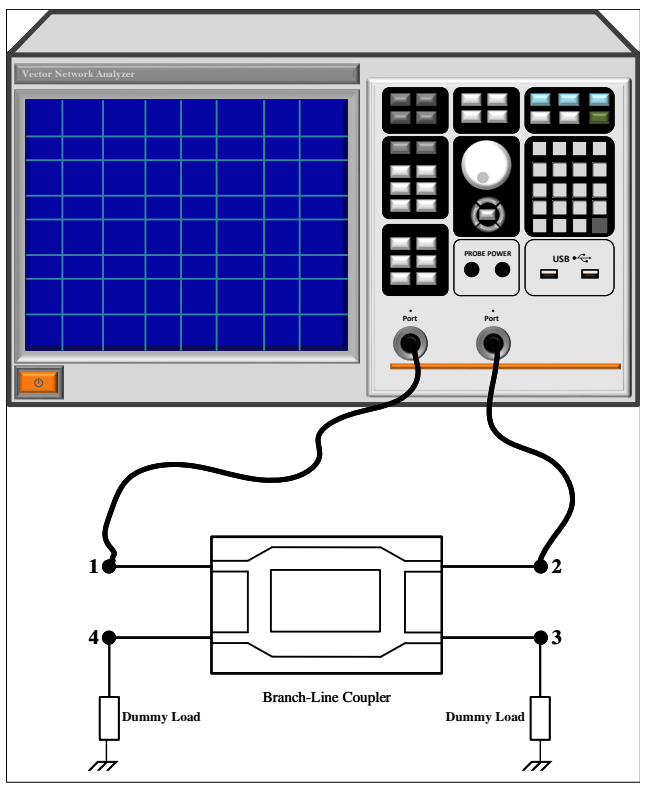

Gambar 5. Pengukuran Realisasi Branch-Line Coupler

\subsection{Pergeseran Fasa Hasil Simulasi}

Untuk memeriksa karakteristik pergeseran fasa, maka ditinjau dari fasa output-nya. Dari hasil simulasi pada Gambar 6, ditunjukkan bahwa pada frekuensi tengah 5,8 GHz didapatkan fasa pada S12 sebesar 92,554 dan fasa pada S13 sebesar 2,909 sehingga perbedaan fasa antara S12 dan S13 sebesar 89,646. Pada rentang frekuensi 5,7-5,9 $\mathrm{GHz}$ memiliki perbedaan fasa mendekati 90 seperti yang ditunjukkan pada Tabel 1 .

\subsection{Pergeseran Fasa Hasil Realisasi}

Perancangan branch-line coupler dengan kebutuhan sebagai rangkaian penggeser fasa 90. Untuk memeriksa karakteristik pergeseran fasa direalisasikan, maka ditinjau dari fasa output-nya. Pergeseran fasa dilihat dari hasil selisih antara fasa output-nya yaitu pada port-2 (P2) dan port-3 (P3).

Hasil pengukuran fasa S12 dan S13 menunjukkan bahwa nilai perbedaan dapat dilihat jelas pada Gambar 7 dan Tabel 2.

\section{Analisa Pergeseran Fasa Branch-Line Coupler}

Branch-line coupler merupakan salah satu rangkaian penggeser fasa 90 yang digunakan pada I/Q demodulator untuk membagi sinyal dari LO menjadi dua buah sinyal yang berbeda fasa sebesar 90. Pada I/Q demodulator, sinyal masukkan akan dikalikan dengan dua sinyal dari local oscillator yang masing-masing berbeda fasa sebesar 90. Gambar 8 menunjukkan bahwa pada keluaran dari LPF (Low Pass Filter) setelah terjadi tahap pengalian merupakan sinyal yang sama dengan 


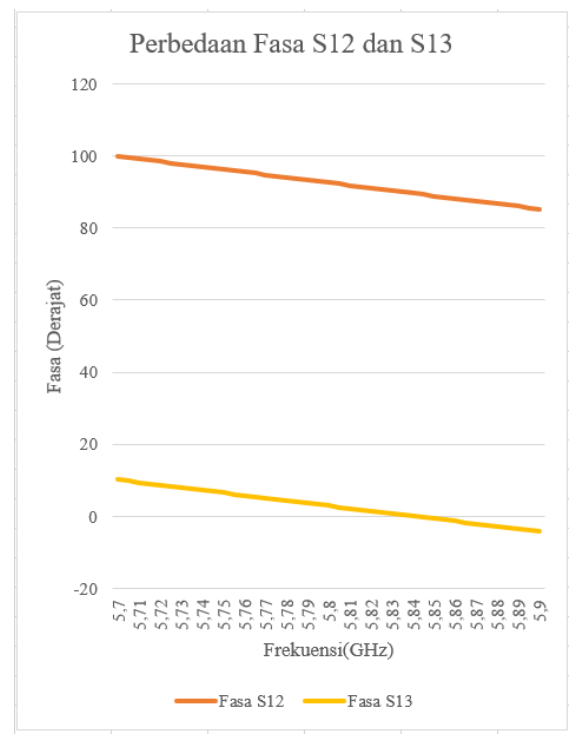

\section{Gambar 6. Perbedaan Fasa Berdasarkan Hasil Simulasi}

besar sinyal masukkan. Sehingga untuk menghitung besar hasil keluaran I (In-phase) dan Q (Quadrature) adalah sesuai dengan persamaan (3), (4), dan (5):

$$
\begin{gathered}
I=A \cos \left(2 \pi f_{0} t+\theta\right) \cdot \cos \left(2 \pi f_{0} t\right) \\
I=\frac{A}{2} \cos \left(4 \pi f_{0} t+\theta\right)+\frac{A}{2} \cos (\theta) \\
I=\frac{A}{2} \cos (\theta)
\end{gathered}
$$

Untuk nilai keluaran dari Q (Quadrature) adalah: mengikuti persamaan (6), (7), dan (8).

$$
\begin{gathered}
Q=A \cos \left(2 \pi f_{0} t+\theta\right) \cdot \cos \left(2 \pi f_{0}+\theta_{\text {shifter }}\right) \\
Q=\frac{A}{2} \cos \left(4 \pi f_{0} t+\theta+\theta_{\text {shifter }}\right)+\frac{A}{2} \cos \left(\theta+\theta_{\text {shifter }}\right) \\
Q=\frac{A}{2} \cos \left(\theta+\theta_{\text {shifter }}\right)
\end{gathered}
$$

dimana:

$\theta=$ fasa sinyal datang.

$\theta_{\text {shifter }}=$ besar pergeseran fasa

$I=$ sinyal In-phase.

$Q=$ sinyal Quadrature.

Untuk mendapatkan nilai yang sama antara nilai masukkan dan nilai keluaran, maka dibutuhkan
Tabel 1. Perbedaan Fasa Berdasarkan Hasil Simulasi.

\begin{tabular}{|c|c|c|c|}
\hline Frek $(\mathbf{G H z})$ & Fasa $\boldsymbol{S}_{\mathbf{1 2}}\left({ }^{\cdot}\right)$ & Fasa $\boldsymbol{S}_{\mathbf{1 3}}\left({ }^{\cdot}\right)$ & $\boldsymbol{\Delta} \boldsymbol{\theta}\left({ }^{\cdot}\right)$ \\
\hline 5,70 & 99,874 & 10,164 & 89,709 \\
\hline 5,71 & 99,142 & 9,427 & 89,716 \\
\hline 5,72 & 98,410 & 8,692 & 89,719 \\
\hline 5,73 & 97,678 & 7,960 & 89,719 \\
\hline 5,74 & 96,946 & 7,230 & 89,716 \\
\hline 5,75 & 96,214 & 6,504 & 89,710 \\
\hline 5,76 & 95,482 & 5,780 & 89,702 \\
\hline 5,77 & 95,750 & 5,059 & 89,691 \\
\hline 5,78 & 94,018 & 4,340 & 89,678 \\
\hline 5,79 & 93,286 & 3,623 & 89,663 \\
\hline 5,80 & 92,554 & 2,909 & 89,646 \\
\hline 5,81 & 91,822 & 2,196 & 89,626 \\
\hline 5,82 & 91,091 & 1,486 & 89,605 \\
\hline 5,83 & 90,359 & 0,778 & 89,581 \\
\hline 5,84 & 89,627 & 0,071 & 89,559 \\
\hline 5,85 & 88,890 & $-0,634$ & 89,529 \\
\hline 5,86 & 87,164 & $-1,337$ & 89,500 \\
\hline 5,87 & 87,432 & $-2,038$ & 89,470 \\
\hline 5,88 & 86,699 & $-2,738$ & 89,438 \\
\hline 5,89 & 85,967 & $-3,437$ & 89,404 \\
\hline 5,90 & 85,234 & $-4,134$ & 89,368 \\
\hline
\end{tabular}

pergeseran fasa sebesar 90, hal itu dibuktikan pada persamaan (9) berikut:

$$
Q_{\text {shifter }}=\tan ^{-1}\left(\frac{Q}{I}\right)
$$

$$
\begin{gathered}
Q_{\text {out put }}=\tan ^{-1}\left(\frac{\frac{A}{2} \cos \left(\theta-\theta_{\text {shifter }}\right)}{\frac{A}{2} \cos (\theta)}\right) \\
Q_{\text {out put }}=\tan ^{-1}\left(\frac{\frac{A}{2} \cos \left(\theta-90^{\circ}\right)}{\frac{A}{2} \cos (\theta)}\right) \\
Q_{\text {out put }}=\tan ^{-1}\left(\frac{\sin (\theta)}{\cos (\theta)}\right) \\
Q_{\text {out put }}=\tan ^{-1}(\theta)
\end{gathered}
$$

Dengan menggunakan persamaan (9)-(13), maka dapat digunakan untuk menganalisa pengaruh pengggeseran fasa pada hasil simulasi dan pengukuran. Nilai pergeseran fasa sendiri diambil dari hasil simulasi pada Tabel 1 dan hasil pengukuran pada Tabel 2. Untuk menentukan pengaruh pergeseran fasa maka di asumsikan nilai fasa sinyal datang sebesar 30, 45, 60, 75 . Dengan menggunakan asumsi tersebut maka nilai dari fasa sinyal datang dan nilai dari fasa sinyal keluaran dapat dibandingkan. 


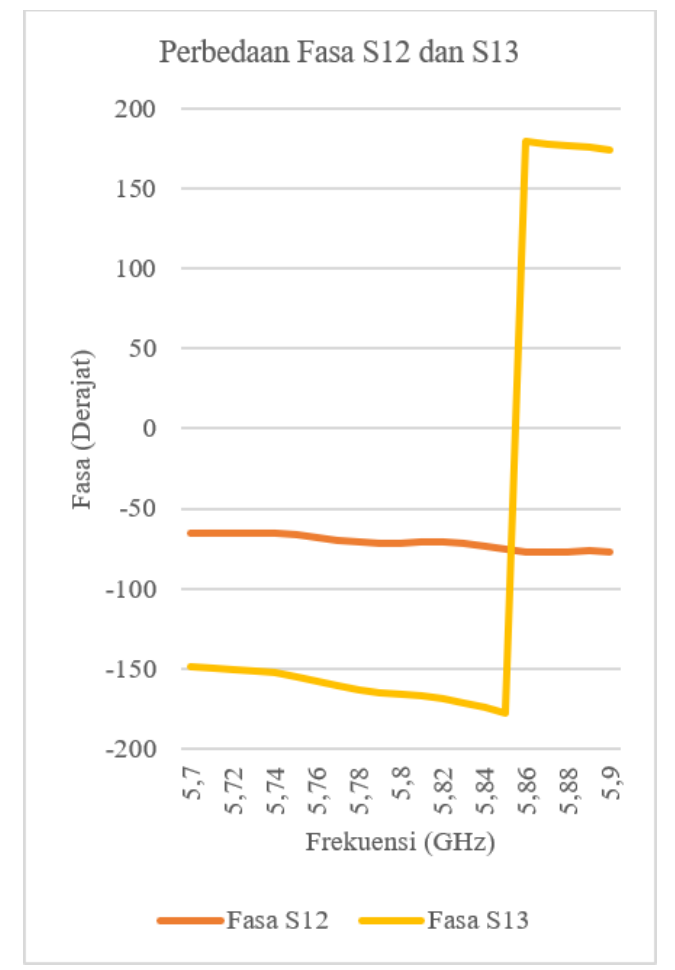

\section{Gambar 7. Perbedaan Fasa Berdasarkan Hasil} Realisasi

\subsection{Analisa Pengaruh Pergeseran Fasa pada Hasil Simulasi}

Berikut ini merupakan tabel yang menunjukkan perbandingan nilai antara fasa sinyal datang dan fasa nilai keluaran yang ditunjukkan pada Tabel 3 .

Tabel 3 menunjukkan deteksi nilai fasa sinyal keluaran dari branch-line coupler hasil dari simulasi. Berdasarkan Tabel 3, rata-rata pergeseran fasa hampir mendekati nilai 90, sehingga nilai fasa keluaran yang mendekati nilai dari fasa sinyal datang. Dapat dilihat bahwa perbedaan yang paling minimum antara fasa sinyal datang dan fasa sinyal keluaran pada pergeseran fasa adalah 89,719, yaitu fasa sinyal datang 30 dengan fasa sinyal keluaran 30,21, fasa sinyal datang 45 dengan fasa sinyal keluaran 45,13981, fasa sinyal datang 60 dengan fasa sinyal keluaran 60,0698 , dan ketika fasa sinyal datang 75 dengan fasa sinyal keluaran 75,01863. Hal ini berbanding terbalik pada saat nilai pergeseran fasa sebesar 89,638 yaitu memiliki nilai selisih maksimum antara fasa sinyal datang dengan fasa sinyal keluaran. Dari data pada Tabel 3, maka dapat dicari nilai persentase error atau selisih yang diakibatkan besar kecilnya nilai pergeseran fasa. Gambar 9 menunjukkan persentase error terhadap besar pergeseran fasa.

GAmbar 9 menunjukkan grafik persentase error yang diakibatkan pergeseran fasa. Dapat dilihat bahwa ketika pergeseran fasa memiliki nilai mendekati nilai 90,
Tabel 2. Perbedaan Fasa Berdasarkan Hasil Simulasi.

\begin{tabular}{|c|c|c|c|}
\hline Frek $(\mathbf{G H z})$ & Fasa $\boldsymbol{S}_{\mathbf{1 2}}\left(^{\circ}\right)$ & Fasa $\boldsymbol{S}_{\mathbf{1 3}}\left(^{\circ}\right)$ & $\Delta \boldsymbol{\theta}\left(^{\circ}\right)$ \\
\hline 5,70 & $-65,301$ & $-148,775$ & 83,474 \\
\hline 5,71 & $-65,706$ & $-150,003$ & 84,297 \\
\hline 5,72 & $-65,702$ & $-150,505$ & 84,803 \\
\hline 5,73 & $-65,520$ & $-151,082$ & 85,562 \\
\hline 5,74 & $-65,575$ & $-152,440$ & 86,864 \\
\hline 5,75 & $-66,256$ & $-154,755$ & 88,499 \\
\hline 5,76 & $-67,695$ & $-157,790$ & 90,095 \\
\hline 5,77 & $-69,468$ & $-160,864$ & 91,396 \\
\hline 5,78 & $-70,912$ & $-163,387$ & 92,472 \\
\hline 5,79 & $-71,498$ & $-164,990$ & 93,493 \\
\hline 5,80 & $-71,203$ & $-165,881$ & 94,677 \\
\hline 5,81 & $-70,549$ & $-166,753$ & 96,204 \\
\hline 5,82 & $-70,462$ & $-168,292$ & 97,831 \\
\hline 5,83 & $-71,456$ & $-170,939$ & 99,484 \\
\hline 5,84 & $-73,397$ & $-174,344$ & 100,947 \\
\hline 5,85 & $-75,641$ & $-177,870$ & 102,229 \\
\hline 5,86 & $-77,186$ & 179,284 & $-256,470$ \\
\hline 5,87 & $-77,309$ & 177,610 & $-254,918$ \\
\hline 5,88 & $-76,668$ & 176,729 & $-253,393$ \\
\hline 5,89 & $-76,248$ & 175,786 & $-252,034$ \\
\hline 5,90 & $-77,015$ & 173,942 & $-250,957$ \\
\hline & & & \\
\hline
\end{tabular}

yaitu pergeseran fasa sebesar 89,719 akan memiliki nilai persentase error paling kecil sebesar $0,6951 \%$ untuk fasa sinyal datang $30,0,3097 \%$ untuk fasa sinyal datang 45 , $0,1162 \%$ untuk fasa sinyal datang 60 , dan $0,0248 \%$ untuk fasa sinyal datang 75 . Dan untuk nilai pergeseran fasa menjauhi dari 90 memiliki persentase error paling besar, seperti pada pergeseran fasa 89,368 yaitu dengan fasa sinyal datang 30 persentase error yang terjadi sebesar $1,5432 \%$, fasa sinyal datang 45 persentase error yang terjadi sebesar $0,6897 \%$, fasa sinyal datang 60 persentase error yang terjadi sebesar $0,2589 \%$, dan fasa sinyal datang 75 persentase error yang terjadi sebesar $0,0551 \%$. Oleh karena itu, dapat disimpulkan bahwa ketika nilai pergeseran fasa semakin mendekati nilai 90 , maka selisih antara nilai fasa sinyal datang dan fasa sinyal keluaran semakin kecil atau bisa dikatakan fasa sinyal keluaran sebanding dengan nilai fasa sinyal datang hal itu dapat dilihat pada Tabel 3 dan Gambar 9, sedangkan untuk pergeseran fasa yang nilainya menjauhi 90, fasa sinyal keluaran memiliki nilai yang cukup besar atau bisa dikatakan memiliki selisih yang cukup besar terhadap nilai fasa sinyal datang, sehingga nilai dari fasa sinyal keluaran nilainya tidak sama dengan nilai fasa sinyal datang. 


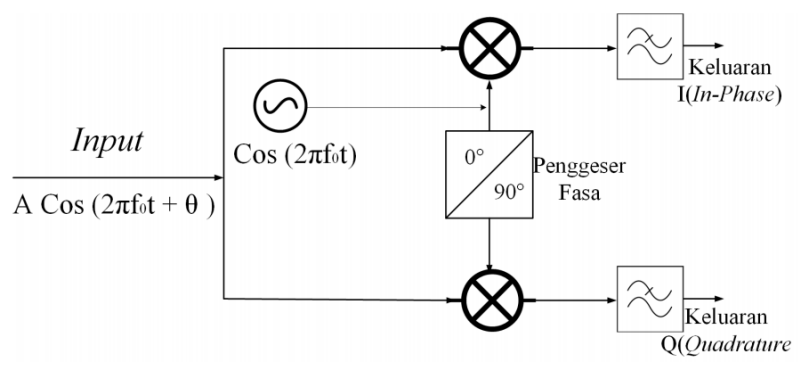

Gambar 8. Kebutuhan I/Q Demodulator untuk Rangkaian Penggeser Fasa

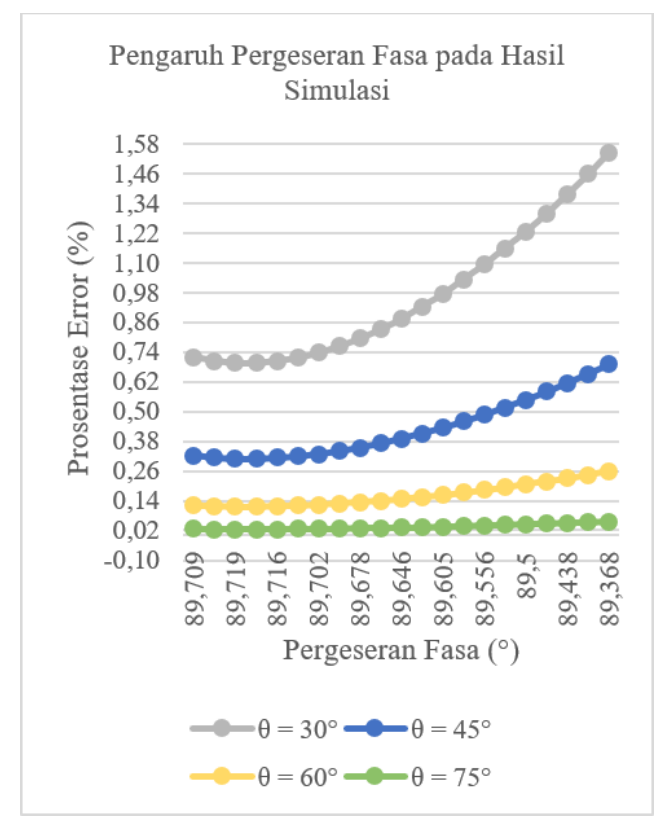

Gambar 9. Grafik Persentase Error Terhadap Pergeseran Fasa Hasil Simulasi

\subsection{Analisa Pengaruh Pergeseran Fasa pada Hasil Realisasi}

Tabel 4 menunjukkan deteksi nilai fasa sinyal keluaran dari branch-line coupler hasil dari pengukuran. Berdasarkan Tabel 4, rata-rata pergeseran fasa menjauhi nilai 90 maka selisih antara nilai fasa keluaran dan nilai dari fasa sinyal datang cukup besar. Dapat dilihat bahwa perbedaan selisih yang paling minimum antara fasa sinyal datang dan fasa sinyal keluaran pada pergeseran fasa 90,095, yaitu fasa sinyal datang 30 dengan fasa sinyal keluaran 29,928 , fasa sinyal datang 45 dengan fasa sinyal keluaran 44,952, fasa sinyal datang 60 dengan fasa sinyal keluaran 59,976, dan ketika fasa sinyal datang 75 dengan fasa sinyal keluaran 74,003 . Hal itu berbanding terbalik pada saat nilai pergeseran fasa sebesar 250,957 yaitu memiliki nilai selisih maksimum antara nilai fasa
Tabel 3. Perbandingan Fasa Sinyal Datang dan Keluaran pada Simulasi.

\begin{tabular}{|c|c|c|c|c|}
\hline$\Delta \theta$ & $\theta=30^{*}$ & $\theta=45^{*}$ & $\theta=60^{*}$ & $\theta=75^{*}$ \\
\hline 89,709 & 30,217 & 45,144 & 60,072 & 75,019 \\
\hline 89,716 & 30,212 & 45,141 & 60,070 & 75,018 \\
\hline 89,719 & 30,210 & 45,139 & 60,069 & 75,018 \\
\hline 89,719 & 30,210 & 45,139 & 60,069 & 75,018 \\
\hline 89,716 & 30,212 & 45,141 & 60,072 & 75,019 \\
\hline 89,710 & 30,216 & 45,144 & 60,072 & 75,019 \\
\hline 89,702 & 30,222 & 45,148 & 60,074 & 75,019 \\
\hline 89,691 & 30,230 & 45,153 & 60,076 & 75,020 \\
\hline 89,678 & 30,240 & 45,160 & 60,079 & 75,021 \\
\hline 89,663 & 30,251 & 45,167 & 60,083 & 75,022 \\
\hline 89,646 & 30,264 & 45,175 & 60,087 & 75,023 \\
\hline 89,626 & 30,279 & 45,185 & 60,092 & 75,024 \\
\hline 89,605 & 30,294 & 45,196 & 60,097 & 75,026 \\
\hline 89,581 & 30,312 & 45,207 & 60,103 & 75,027 \\
\hline 89,556 & 30,331 & 45,220 & 60,109 & 75,029 \\
\hline 89,529 & 30,351 & 45,233 & 60,116 & 75,031 \\
\hline 89,500 & 30,372 & 45,247 & 60,123 & 75,032 \\
\hline 89,470 & 30,394 & 45,262 & 60,130 & 75,034 \\
\hline 89,438 & 30,418 & 45,278 & 60,138 & 75,036 \\
\hline 89,404 & 30,443 & 45,294 & 60,147 & 75,039 \\
\hline 89,368 & 30,470 & 45,312 & 60,155 & 75,041 \\
\hline
\end{tabular}

sinyal datang dengan nilai fasa sinyal keluaran. Dari data pada Tabel 4, maka dapat dicari nilai persentase error atau selisih yang diakibatkan besar kecilnya nilai pergeseran fasa. Berikut grafik yang menunjukkan hubungan antara besar pergeseran fasa terhadap persentase error Gambar 10.

Pada Gambar 10, menunjukkan persentase error yang terjadi yang diakibatkan pergeseran fasa. Dapat dilihat bahwa ketika pergeseran fasa memiliki nilai mendekati nilai 90 yaitu pergeseran fasa sebesar 90,095 memiliki nilai persentase error paling kecil sebesar $0,2384 \%$ untuk fasa sinyal datang $30,0,1058 \%$ untuk fasa sinyal datang $45,0,0397 \%$ untuk fasa sinyal datang 60 , dan $0,0085 \%$ untuk fasa sinyal datang 75 . Dan untuk nilai pergeseran fasa menjauhi dari 90, memiliki persentase error paling besar, seperti pada pergeseran fasa sebesar 250,957 yaitu dengan fasa sinyal datang 30 prosentase error yang terjadi sebesar 142,3497\%, fasa sinyal datang 45 persentase error yang terjadi sebesar 41,6995\%, fasa sinyal datang 60 persentase error yang terjadi sebesar $13,9295 \%$, dan fasa sinyal datang 75 persentase error yang terjadi sebesar 3,2293\%. Oleh karena itu, dapat disimpulkan bahwa ketika nilai pergeseran fasa semakin mendekati nilai 90, maka selisih antara nilai fasa sinyal datang dan fasa sinyal keluaran semakin kecil atau bisa dikatakan fasa sinyal keluaran nilai mendekati atau sebanding dengan nilai fasa sinyal datang hal itu dapat dilihat pada Tabel 4 dan Gambar 10. 
Tabel 4. . Perbandingan Fasa Sinyal Datang dan Keluaran pada Realisasi.

\begin{tabular}{|c|c|c|c|c|}
\hline$\Delta \theta$ & $\theta=30$ & $\theta=45$ & $\theta=60$ & $\theta=75$ \\
\hline 83,474 & 34,49931 & 47,91165 & 61,40462 & 75,33588 \\
\hline 84,297 & 33,97463 & 47,58130 & 61,25120 & 75,30434 \\
\hline 84,803 & 33,64604 & 47,05360 & 61,00256 & 75,24991 \\
\hline 85,562 & 33,14451 & 47,05360 & 61,00256 & 75,24991 \\
\hline 86,864 & 32,2597 & 46,48448 & 60,72994 & 75,18623 \\
\hline 88,499 & 31,10454 & 45,73109 & 60,36267 & 75,09503 \\
\hline 90,095 & 29,92866 & 44,95242 & 59,97620 & 74,99361 \\
\hline 91,396 & 28,93454 & 44,28478 & 59,63980 & 74,90162 \\
\hline 92,475 & 28,08564 & 43,70787 & 59,34563 & 74,81878 \\
\hline 93,492 & 27,26518 & 43,14428 & 59,05533 & 74,73514 \\
\hline 94,677 & 26,28428 & 42,46262 & 58,70052 & 74,63068 \\
\hline 96,204 & 24,98082 & 41,54334 & 58,21595 & 74,48461 \\
\hline 97,831 & 23,54345 & 40,51133 & 57,66402 & 74,31418 \\
\hline 99,484 & 22,03252 & 39,40514 & 57,06345 & 74,12465 \\
\hline 100,947 & 20,65361 & 38,37579 & 56,49646 & 73,94244 \\
\hline 102,229 & 19,41399 & 37,43367 & 55,97074 & 73,77107 \\
\hline 256,47 & 18,12705 & 36,43820 & 55,40822 & 73,58544 \\
\hline 254,918 & 16,55521 & 35,19735 & 54,69689 & 73,34776 \\
\hline 253,393 & 14,97396 & 33,92013 & 53,95275 & 73,09605 \\
\hline 252,034 & 13,53614 & 32,73239 & 53,24960 & 72,85566 \\
\hline 250,957 & 12,37881 & 31,75735 & 52,66414 & 72,65379 \\
\hline
\end{tabular}

Sedangkan untuk pergeseran fasa yang nilainya menjauhi 90, fasa sinyal keluaran memiliki nilai yang cukup besar atau bisa dikatakan memiliki selisih yang cukup besar terhadap nilai fasa sinyal datang, sehingga nilai dari fasa sinyal keluaran nilainya tidak sama dengan nilai fasa sinyal datang. Untuk mendapatkan hasil fasa sinyal keluaran sama dengan fasa sinyal datang, maka diperlukan pergeseran fasa sebesar 90 .

\section{Kesimpulan}

Penelitian ini difokuskan pada analisa kerja branch-line coupler hasil dari perancangan dan realisasi untuk mendeteksi fasa pada radar $C$-band dengan basis I/Q demodulator. Berdasarkan penelitian yang telah dilakukan didapatkan nilai antara hasil dari pergeseran fasa baik berdasarkan simulasi maupun pengukuran realisasi branch-line coupler. Dapat disimpulkan bahwa pergeseran fasa mempengaruhi hasil dari nilai fasa sinyal keluaran, semakin nilai pergeseran fasa mendekati 90 maka nilai fasa keluaran akan sebanding dengan nilai fasa sinyal datang.

\section{Daftar Pustaka}

[1] A. Farina, "Introduction to radar signal and data processing: the opportunity," Selex Sistemi Integrati

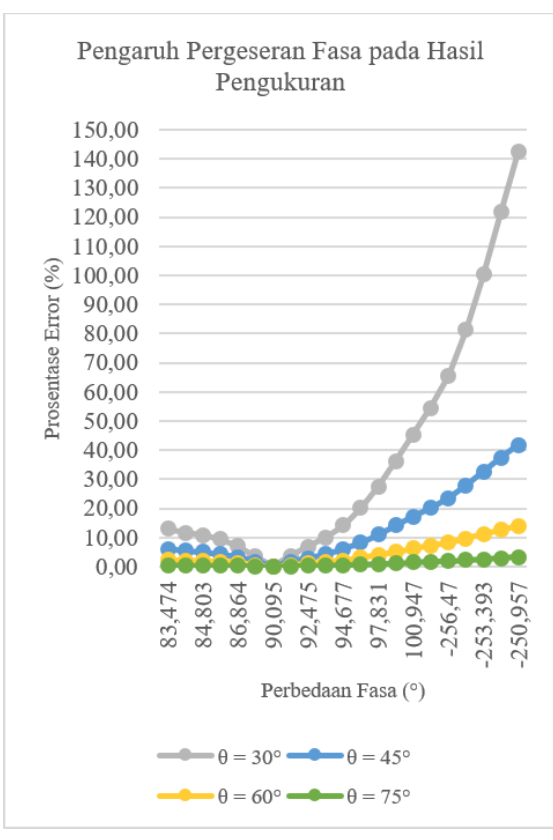

\section{Gambar 10. Grafik Persentase Error Terhadap Pergeseran Fasa Hasil Pengukuran Realisasi}

Rome (Italy), Tech. Rep., 2006.

[2] C. Ziomek and P. Corredoura, "Digital i/q demodulator," in Proceedings Particle Accelerator Conference, vol. 4. IEEE, 1995, pp. 2663-2665.

[3] D. M. Pozar, "Microwave engineering," Fourth Editions, University of Massachusetts at Amherst, John Wiley \& Sons, Inc, pp. 26-30, 2012.

[4] L. Sun, Y.-Z. Yin, X. Lei, and V. Wong, "A novel miniaturized branch-line coupler with equivalent transmission lines," Progress In Electromagnetics Research Letters, vol. 38, pp. 35-44, 2013.

[5] J. Kirkhorn, "Introduction to iq-demodulation of rfdata," IFBT, NTNU, vol. 15, 1999.

[6] B. R. Mahafza, Radar Systems Analysis and Design Using MATLAB Third Edition. CRC press, 2013.

[7] D. A. Letavin, Y. E. Mitelman, and V. A. Chechetkin, "The substrate factor in the miniaturization efficiency of the microstrip branch-line couplers," in 2016 24th Telecommunications Forum (TELFOR). IEEE, 2016, pp. 1-4. 